Dept. of Clinical Nutrition and Animal Nutrition

Faculty of Veterinary Medicine

\title{
THE USE OF UNTRADITIONAL RATION CONSTITUENTS IN FEEDING OF GROWING DUCKS A- DRIED POULTRY WASTE \\ (With 6 Tables)
}

By
G.M. MOSAAD, A.M. ABDELLAH, A.N. SAYED and RASHA I. HASSAN

(Received at 10/10/2009)

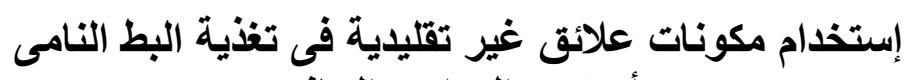

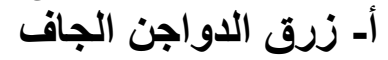

جمال مهنى مسعد ، عبل الستار محمد عبل اللاه ، عبد الباسط نصر سبي ، رشا

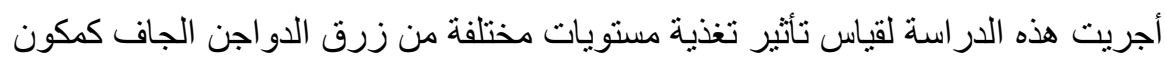

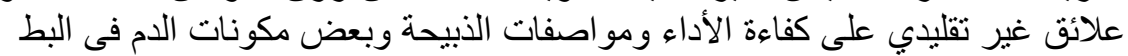

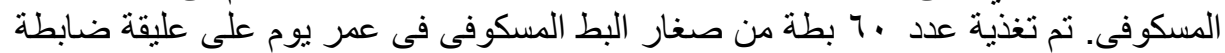

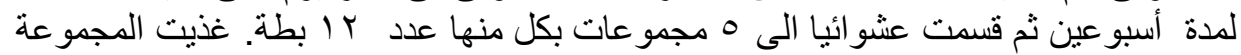

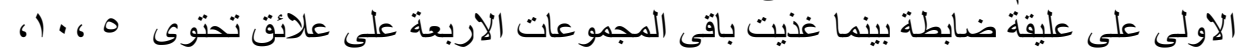

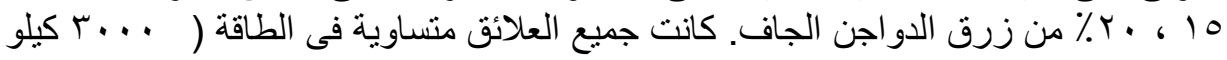

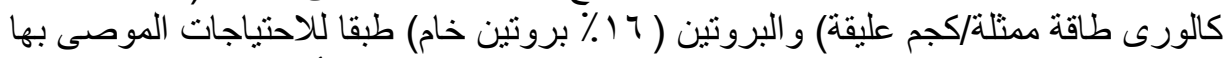

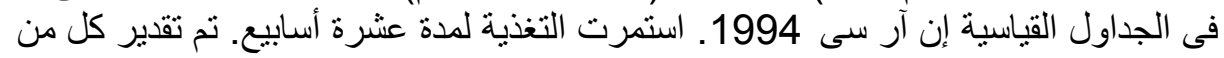

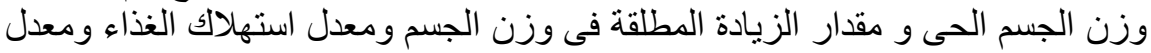

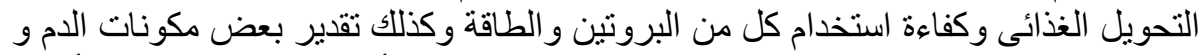

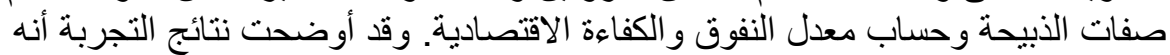

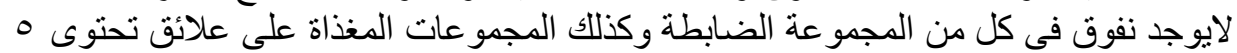

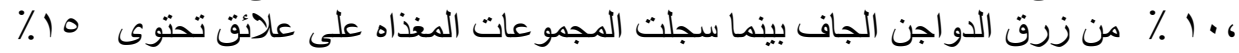

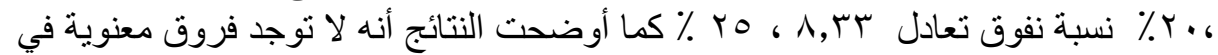

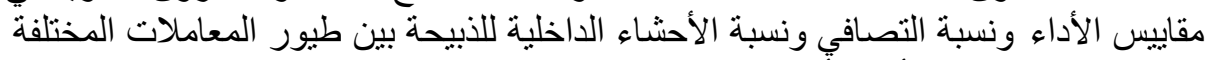

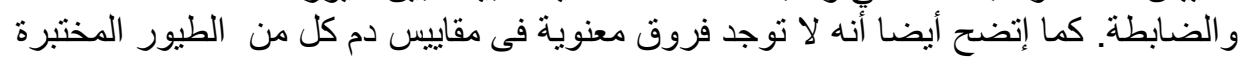

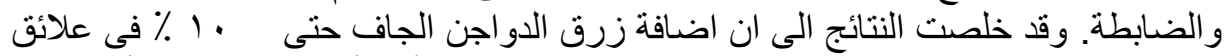

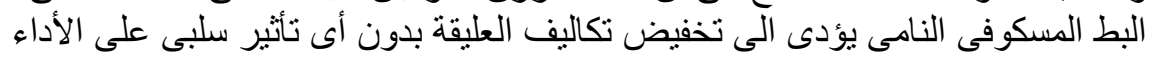

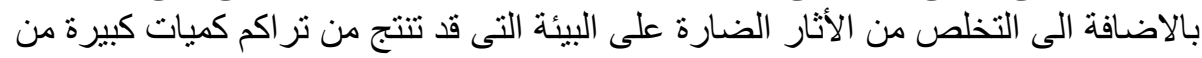

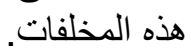


The present study was performed to investigate the effect of feeding different levels of dried poultry waste (DPW) as untraditional ration constituent on duck performance, carcass traits and some blood biochemical constituents. 60 unsexed one day old Muscovy ducklings were fed ad-libitum on a control starter diet until 2 weeks of age. At that time, they were wighed and randomly distributed into 5 groups each of 12 ducklings. The first group was considered as a control (T1) and was fed ad libitum on a grower/ finisher diet. The other four groups (T2, T3, T4 \& T5) were fed diets containing DPW at levels of 5, 10, 15 and 20\% respectively. All diets were formulated to be isocaloric $(3000 \mathrm{kcal} / \mathrm{kg}$ $\mathrm{ME}$ ), isonitrogenous (16\% CP) as recommended by NRC (1994) for growing ducks. The experiment was extended for 10 weeks. The body weight development, body weight gain, feed intake, feed conversion ratio, protein efficiency ratio and caloric efficiency ratio were determined. In addition, some blood constituents, carcass traits, mortality rate and economical evaluation were also measured. The results showed that, there were no mortalities in control group and groups fed diets with 5 and 10\% DPW. However groups fed on diets with $15 \%$ and $20 \%$ dried poultry waste recorded $8.33 \%$ and $25.0 \%$ mortality rate, respectively. There were no significant differences, in performance measurements between control group and other treatments. There were no significant differences between control group and other treatments in carcass dressing percentage and relative percentage of internal organs. Also, there were no significant differences in blood parameters between control group and other treatments. It could be concluded that, addition of dried poultry waste to the duck diets up to $10 \%$ leads to decrease in the cost of the ration without any adverse effect on the duck performance and may help to alleviate pollution problems.

Key words: Ducks, feeding, dried poultry waste, performance.

\section{INTRODUCTION}

In the developing countries in particular increases in population practically erodes increases in food production leaving no hope of ever having surplus grains to compound economically viable livestock feeds (Christopher et al., 1997 and Onimisi, 2005). Generally, feed accounts for upward of $60 \%$ of the total costs of raising farm animals. Shortage of the conventional feedstuffs like maize and soybeans (which has led to the high costs of feeds for livestock) is occasioned by the competition 
between man and livestock for these feed sources (Vander Zijpp, 1997). In Egypt, a considerable attention has been paid to use such untraditional cheap and good feedstuffs in formulating animals and poultry diets to achieve a suitable efficiency of utilization and economic efficiency of production to overcome the feed shortage of livestock. Increasing poultry production through low cost feeds will therefore be of immense contribution to the quest for increased animal protein supply in most of our developing countries. There is therefore an urgent need for alternative locally available and cheap sources of feed ingredients particularly those that do not attract competition in consumption between human and livestock. Much efforts are being made to study the possibilities of utilizing poultry manure in the nutrition of animals including poultry (Henuk and Dingle, 2002). This can lead to a reduction of traditional feed ingredients such as maize, wheat and soybeans that can be consumed by humans and considered as animal feeds (El-Boushy and Van der Poel, 2000). In addition, utilization of animal excreta for feed nutrients may help to alleviate pollution problems, decrease feed costs and increase the supplies of available nitrogen and essential mineral sources (Arndt et al., 1979). In feeding poultry wastes to livestock, the first limiting factor is energy, the secondary limiting factor is a high ash content which limits the level of poultry wastes that can be used. The nutritive value of poultry droppings is dependent on producing species, age of waste, feeding plan of producing animal, housing and management system and handling, storage and processing of waste (Smith, 1981). Dried poultry manure after proper treatment could be used as feedstuff because it contains microorganisms able to convert some of uric acid to microbial protein can be utilized by poultry (El-Boushy and Vink, 1977). The present study was carried out to evaluate the effects of feeding dried poultry waste on performance, carcass traits and some blood biochemical parameters of ducklings.

\section{MATERIALS and METHODS}

\section{Birds and housing}

60 Muscovy ducklings of one-day old were obtained from local commercial source and were fed ad libitum on a control starter diet until 2 weeks of age. At that time, all ducklings were weighed and randomly distributed into 5 equal groups, each of 12. Birds had a similar initial average weight $(402.53 \pm 10.17 \mathrm{~g})$. Birds were housed in a room previously disinfected with $4 \%$ formalin and divided into compartments each of $2 \mathrm{~m}^{2}$ floor area and bedded with a layer of chaffed wheat straw. 
Experimental compartments were equipped with a cylindrical galvanized feeder, waterers, thermostatically controlled heaters and ventilation fans to maintain room temperature and air flow. Birds were vaccinated at 7 days of age against Avian Influenza Virus (H5N2). The prophylactic measures were taken to control diseases and to increase the viability of the birds. The experiment was carried out in Dept. of animal and clinical nutrition, Assiut University, Egypt.

\section{Diets and feeding}

Five levels of dried poultry waste (DPW; 0, 5, 10, 15 and 20\%) were added to the diets of T1, T2, T3, T4 and T5 groups, respectively during the period from 2 - 12 weeks of age. Poultry waste used in this study was dried and processed as reported by Fontenot and Webb (1975). Diets were formulated to contain approximately the same crude protein $(16 \%)$ and metabolizable energy $(3000 \mathrm{kcal} / \mathrm{kg}$ diet $)$ levels as recommended by NRC (1994). The leg banded ducklings in the five groups were fed ad libitum on the respective diets in mash form and given free access to fresh and clean water throughout the experimental period. The composition and metabolizable energy value of the ingredients and the experimental diets are presented in tables 1 and 2.

Table 1: Chemical composition (\%) and metabolizable energy value of the ingredients

\begin{tabular}{|l|l|l|l|l|l|l|}
\hline \multicolumn{1}{|c|}{ Ingredients } & $\begin{array}{l}\text { Yellow } \\
\text { Corn }\end{array}$ & $\begin{array}{l}\text { Soybean } \\
\text { meal }\end{array}$ & $\begin{array}{l}\text { Fish } \\
\text { meal }\end{array}$ & $\begin{array}{l}\text { Wheat } \\
\text { Bran }\end{array}$ & $\begin{array}{l}\text { Dried } \\
\text { Fat }\end{array}$ & DPW* \\
\hline Dry matter & 88.50 & 91.12 & 95.00 & 91.00 & 96.25 & 93.20 \\
Crude protein & 8.60 & 45.00 & 39.50 & 14.51 & 4.68 & 25.00 \\
Ether- extract & 4.68 & 3.28 & 14.50 & 5.45 & 55.98 & 4.06 \\
Crude fiber & 2.22 & 6.55 & 0.81 & 11.00 & 3.36 & 15.36 \\
Nitrogen free-extract & 71.89 & 30.44 & 1.88 & 55.49 & 11.23 & 28.28 \\
Ash & 1.11 & 5.85 & 38.31 & 4.55 & 21.00 & 20.50 \\
Calcium & 0.03 & 0.36 & 5.36 & 0.18 & 2.75 & 4.48 \\
Total phosphorus & 0.31 & 0.66 & 2.25 & 1.35 & 0.42 & 1.29 \\
Lysine & 0.26 & 2.69 & 1.37 & 1.73 & 0.00 & 0.41 \\
Methionine & 0.18 & 0.62 & 0.50 & 0.50 & 0.00 & 0.16 \\
ME (kcal/kg diet)** & 3390 & 2372 & 2712 & 1647 & 5271 & 2252 \\
\hline
\end{tabular}

* DPW= Dried poultry waste

** ME calculated, according to Janssen (1989) and Carpenter and Clegg (1956).

Table 2: Composition of the experimental diets 


\begin{tabular}{|l|l|l|l|l|l|}
\hline \multirow{2}{*}{\multicolumn{1}{c|}{ Ingredients }} & \multicolumn{5}{|c|}{ Treatments } \\
\cline { 2 - 6 } & $\begin{array}{l}\mathrm{T} 1 \\
0 \%\end{array}$ & $\begin{array}{l}\mathrm{T} 2 \\
5 \%\end{array}$ & $\begin{array}{l}\mathrm{T} 3 \\
10 \%\end{array}$ & $15 \%$ & $20 \%$ \\
\hline Physical composition (\%) & & & & & \\
Yellow corn, ground & 43.02 & 51.07 & 55.25 & 55.96 & 54.92 \\
Soybean meal & 14.44 & 12.84 & 11.18 & 9.35 & 7.47 \\
Fish meal & 4.00 & 4.00 & 4.00 & 4.00 & 4.00 \\
Wheat bran & 24.96 & 17.90 & 12.84 & 9.71 & 7.50 \\
Dried fat & 12.90 & 8.50 & 6.00 & 5.22 & 5.28 \\
Poultry waste, dried & 0.00 & 5.00 & 10.00 & 15.00 & 20.00 \\
Common salt & 0.33 & 0.33 & 0.33 & 0.33 & 0.33 \\
Lysine & 0.00 & 0.00 & 0.03 & 0.06 & 0.11 \\
Methionine & 0.05 & 0.06 & 0.07 & 0.07 & 0.09 \\
Premix* & 0.30 & 0.30 & 0.30 & 0.30 & 0.30 \\
\hline Chemical composition (\%) & & & & & \\
Dry matter & 90.84 & 90.51 & 90.39 & 90.42 & 90.57 \\
Crude protein & 16.00 & 16.00 & 16.00 & 16.00 & 16.00 \\
Ether- extract & 11.64 & 9.33 & 8.00 & 7.57 & 7.56 \\
Crude fiber & 5.11 & 5.03 & 5.15 & 5.43 & 5.82 \\
Nitrogen free-extract & 51.38 & 53.67 & 54.53 & 54.10 & 53.06 \\
Ash & 6.71 & 6.48 & 6.71 & 7.32 & 8.13 \\
Calcium & 0.68 & 0.77 & 0.91 & 1.10 & 1.31 \\
phosphorus Total & 0.71 & 0.68 & 0.66 & 0.67 & 0.74 \\
Lysine & 0.72 & 0.68 & 0.65 & 0.65 & 0.65 \\
Methionine & 0.30 & 0.30 & 0.30 & 0.30 & 0.30 \\
ME (kcal/kg diet) & 3000 & 3000 & 3000 & 3000 & 3000 \\
Calorie/protein ratio & 187.5 & 187.5 & 187.5 & 187.5 & 187.5 \\
& & & & & \\
\hline
\end{tabular}

* Each 2.5 kg contains: Vit. A, 12000000 IU; Vit. D 2000000 IU;Vit. E, 10 g; Vit. $\mathrm{k}_{3}, 2 \mathrm{~g}$; Vit. $\mathrm{B}_{1}, 1 \mathrm{~g}$; Vit. $\mathrm{B}_{2}, 5 \mathrm{~g}$; Vit. $\mathrm{B}_{6}, 1.5 \mathrm{~g}$; Vit. $\mathrm{B}_{12}, 10 \mathrm{~g}$; Nicotinic acid $30 \mathrm{~g}$; Pantothenic acid 10g; Folic acid 1g; Biotin $50 \mathrm{~g}$; Choline chloride 5o \% $250 \mathrm{~g}$; Iron 30 g; Copper 10 g; Zinc 50 g; Manganese 60 g; Iodine 1g; Selenium 0.1.

\section{Measurements}

Body weight development $(\mathrm{g})$ and feed intake $(\mathrm{g})$ of ducklings were recorded on 7-days interval until 12 weeks of age. Mortality rate was also monitored on group basis. Feed conversion ratio, protein efficiency ratio (PER) and caloric efficiency ratio (CER) were calculated. The proximate analysis of the experimental feeds was performed using procedures detailed by the Official Analytical Chemistry (AOAC, 1990). Calcium in prepared samples was determined in $\mathrm{g} / \mathrm{kg}$ by using test kits supplied by BIOGAMMA-ITALY Company after the method described by Kaplan and Pesce (1996) using 
colorimetric spectrophotometer. Phosphorus was determined in $\mathrm{g} / \mathrm{kg}$ using the test kits supplied by LABKIT company after the method described by Young (2001).

\section{Carcass traits}

At the end of the experiment, three birds from each group were slaughtered after fasting overnight, processed and the weight of carcass, gizzard, proventriculus, liver, spleen and heart were recorded. Dressed carcass is the weight of the slaughtered birds after removal of feathers, head and feet but including all edible offals. The organs weight was expressed as relative weight proportionate to pre-slaughter live body weight.

\section{Blood samples and biochemistry}

Blood samples were collected from the slaughtered birds, allotted to clot at ambient temperature, centrifuged for 15 minutes at $3000 \mathrm{rpm}$ and then extracted. The serum samples were kept at $-20{ }^{\circ} \mathrm{C}$ until biochemical parameters were measured. Serum total protein and uric acid was determined using commercial kits (SGM Italia Company) based on the methods outlined by Kaplan and Pesce (1996). Serum albumin was determined using commercial kits (BIOCON Company) after the method described by Marshall (1989). Serum urea was determined using commercial kits (DP International Company) based on the methods outlined by Patton and Crouch (1977).

\section{Statistical analysis}

Statistical analysis of the obtained data was carried out according to procedures of completely random design SPSS (2001).

\section{RESULTS}

The results in table 3 indicated that, there was no significant difference in body weight and weight gain between control and tested groups, however, a significant difference was found between tested groups. The values of feed intake and feed conversion were increased with increase the level of DPW, however, PER and CER were decreased. Groups fed diets with 15 and 20\% DPW had a mortality percentage of 8.33 and $25.0 \%$, respectively.

Table 3: Performance and mortality rate of ducks fed different levels of dried poultry waste 
Assiut Vet. Med. J. Vol. 56 No. 124 January 2010

\begin{tabular}{|l|c|c|c|c|c|}
\hline \multirow{2}{*}{\multicolumn{1}{c|}{ Item }} & \multicolumn{5}{|c|}{ Dried poultry waste (\%) } \\
\cline { 2 - 6 } & $\mathrm{T} 1$ & $\mathrm{~T} 2$ & $\mathrm{~T} 3$ & $\mathrm{~T} 4$ & $\mathrm{~T} 5$ \\
& 0 & 5 & 10 & 15 & 20 \\
\hline Initial weight & $400 \pm 29.5$ & $408.3 \pm 22.9$ & $404.2 \pm 27.8$ & $400.2 \pm 17.1$ & $400 \pm 17.4$ \\
Final weight & $3218 \pm 82.8^{\mathrm{ab}^{*}}$ & $3367 \pm 47.7^{\mathrm{a}}$ & $3425 \pm 110.5^{\mathrm{a}}$ & $3075 \pm 87.6^{\mathrm{b}}$ & $2979 \pm 113.9^{\mathrm{b}}$ \\
Weight gain (g) & $2818 \pm 89.2^{\mathrm{ab}}$ & $2959 \pm 76.8^{\mathrm{a}}$ & $3021 \pm 68.4^{\mathrm{a}}$ & $2694 \pm 79.2^{\mathrm{b}}$ & $2548 \pm 72.6^{\mathrm{b}}$ \\
Feed intake (g) & 10741 & 11370 & 11975 & 11053 & 11156 \\
Feed conversion & 3.81 & 3.84 & 3.96 & 4.10 & 4.38 \\
Protein eff. ratio & 1.64 & 1.63 & 1.58 & 1.52 & 1.43 \\
Caloric eff. ratio & 0.087 & 0.087 & 0.084 & 0.081 & 0.076 \\
Mortality rate & 00.00 & 00.00 & 00.00 & 08.33 & 25.00 \\
\hline
\end{tabular}

* Means within the same row with different superscripts are significantly different $(\mathrm{P}<0.05)$.

Data in table 4 indicated that, serum total protein, albumin, globulin, albumin/globulin ratio, urea and uric acid in ducks were not significantly affected by feeding different levels of dried poultry waste.

Table 4: Blood parameters of ducks in the experiment

\begin{tabular}{|l|l|l|l|l|l|}
\hline \multirow{2}{*}{ Item } & \multicolumn{5}{|l}{ Dried poultry waste (\%) } \\
\cline { 2 - 6 } & $\begin{array}{l}\mathrm{T} 1 \\
0\end{array}$ & $\begin{array}{l}\mathrm{T} 2 \\
5\end{array}$ & $\begin{array}{l}\mathrm{T} 3 \\
10\end{array}$ & $\begin{array}{l}\mathrm{T} 4 \\
15\end{array}$ & $\begin{array}{l}\text { T5 } \\
20\end{array}$ \\
\hline Total protein g/dl & $4.78 \pm 0.04$ & $4.47 \pm 0.03$ & $4.92 \pm 0.03$ & $4.62 \pm 0.04$ & $4.78 \pm 0.02$ \\
Albumin g/dl & $2.23 \pm 0.03$ & $1.96 \pm 0.01$ & $2.25 \pm 0.03$ & $2.08 \pm 0.02$ & $2.22 \pm 0.04$ \\
Globulin g/dl & $2.54 \pm 0.01$ & $2.50 \pm 0.02$ & $2.67 \pm 0.06$ & $2.53 \pm 0.07$ & $2.56 \pm 0.02$ \\
Alb/Glob ratio & $0.88 \pm 0.03$ & $0.79 \pm 0.003$ & $0.84 \pm 0.03$ & $0.82 \pm 0.03$ & $0.87 \pm 0.02$ \\
Urea mg/dl & $24.41 \pm 0.23$ & $24.66 \pm 0.04$ & $24.90 \pm 0.05$ & $25.34 \pm 0.28$ & $27.10 \pm 0.05$ \\
Uric acid mg/dl & $5.75 \pm 0.03$ & $5.45 \pm 0.03$ & $5.44 \pm 0.05$ & $5.83 \pm 0.04$ & $5.94 \pm 0.03$ \\
\hline
\end{tabular}

Carcass traits including carcass weight, dressing percentages, weights of internal organs proportionate to pre-slaughter live body weight are revealed in table 5. There were no significant difference between different groups in these parameters.

Table 5: Carcass traits parameters of ducks in the experiment 
Assiut Vet. Med. J. Vol. 56 No. 124 January 2010

\begin{tabular}{|l|c|c|c|c|c|}
\hline \multirow{2}{*}{\multicolumn{1}{|c|}{ Parameters }} & \multicolumn{5}{|c|}{ Dried poultry waste (\%) } \\
\cline { 2 - 6 } & 0 & 51 & T3 & T4 & 15 \\
\hline & & 5 & 10 & T5 \\
Preslaughter, wt. (gm) & $3433.33 \pm 261$ & $3411.67 \pm 198$ & $3483.33 \pm 166$ & $3416.67 \pm 120$ & $2970 \pm 316$ \\
Evacerated carcass (gm) & $2513 \pm 232$ & $2515.67 \pm 159$ & $2538.67 \pm 144$ & $2557 \pm 85$ & $2222.33 \pm 233$ \\
Carcass (\%) & $73.00 \pm 1.47$ & $73.66 \pm 1.10$ & $72.86 \pm 1.73$ & $74.85 \pm 0.39$ & $74.33 \pm 0.28$ \\
Dressing weight (gm) & $2710 \pm 259$ & $2713.33 \pm 156$ & $2733.33 \pm 158$ & $2761.67 \pm 77$ & $2401.67 \pm 274$ \\
Dressing (\%) & $78.69 \pm 1.91$ & $79.55 \pm 0.64$ & $78.44 \pm 2.00$ & $80.87 \pm 0.57$ & $80.73 \pm 0.66$ \\
Liver, \% & $2.24 \pm 0.13$ & $2.75 \pm 0.26$ & $2.20 \pm 0.19$ & $2.67 \pm 0.33$ & $2.78 \pm 0.11$ \\
Heart, \% & $0.85 \pm 0.08$ & $0.76 \pm 0.01$ & $0.77 \pm 0.03$ & $0.87 \pm 0.02$ & $0.80 \pm 0.03$ \\
Proventriculus, \% & $0.29 \pm 0.01$ & $0.28 \pm 0.06$ & $0.27 \pm 0.03$ & $0.36 \pm 0.01$ & $0.28 \pm 0.06$ \\
Gizzard, \% & $2.60 \pm 0.25$ & $2.51 \pm 0.69$ & $2.61 \pm 0.06$ & $2.48 \pm 0.33$ & $2.83 \pm 0.19$ \\
Spleen, \% & $0.10 \pm 0.00$ & $0.10 \pm 0.00$ & $0.08 \pm 0.003$ & $0.09 \pm 0.00$ & $0.08 \pm 0.00$ \\
& & & & & \\
\hline
\end{tabular}

Economical evaluation of duck performance in the different experimental groups are presented in table (6). Groups fed diets with 5, 10 and $15 \%$ DPW had more economic feed efficiency and relative feed efficiency than control one. However group fed diet with $20 \%$ DPW shows the lowest economic feed efficiency.

Table 6: Economical evaluation of ducks in the experiment

\begin{tabular}{|l|c|c|c|c|c|}
\hline \multirow{2}{*}{\multicolumn{1}{|c|}{ Item }} & \multicolumn{5}{c|}{ Dried poultry waste (\%) } \\
\cline { 2 - 6 } & T1 & T2 & T3 & T4 & T5 \\
& 0 & 5 & 10 & 15 & 20 \\
\hline & & & & & \\
Average feed intake (kg/bird) & 10.74 & 11.37 & 11.98 & 11.05 & 11.16 \\
Price/kg feed (L.E) & 2.75 & 2.12 & 2.11 & 1.97 & 1.91 \\
Total feed cost (L.E) & 29.54 & 24.10 & 25.39 & 21.77 & 21.31 \\
Total production cost (L.E) & 52.04 & 46.60 & 47.89 & 46.32 & 51.31 \\
Body weight (kg/bird) & 3.218 & 3.367 & 3.425 & 3.075 & 2.979 \\
Price/kg body weight (L.E) & 18.00 & 18.00 & 18.00 & 18.00 & 18.00 \\
Total revenue (L.E) & 57.92 & 60.61 & 61.65 & 55.35 & 53.62 \\
Net revenue (L.E) & 5.88 & 14.01 & 13.76 & 9.03 & 2.31 \\
Economic feed efficiency ( \% ) & 11.30 & 30.06 & 28.73 & 19.49 & 4.50 \\
Relative economic feed eff. & 100 & 266.02 & 254.25 & 172.48 & 39.82 \\
& & & & & \\
\hline
\end{tabular}




\section{Growth performance}

The results obtained in table 3 indicated that, the final body weight and weight gain of ducks fed diets with 5 and $10 \%$ dried poultry waste were significantly $(\mathrm{P}<0.05)$ higher than those fed diets with 15 and $20 \%$ dried poultry waste. The results are in agreement with that reported by Hady (1989); Momtaz and Abidur (1990); Nambi et al. (1992); Attia et al. (1993) and Olorede et al. (1995) who recorded that, the level of DPW between 10 and $20 \%$ could be included in broiler diets with no adverse effect on performance. On the contrary, these results was disagreed with that reported by Adeyemo and Oyejola (2004) who revealed that growth of broiler chicks was progressively decreased as the amount of dried poultry waste was increased from 5 to $20 \%$. The generally better growth performance achieved by birds fed DPW might have contributed to the unidentified growth factor reported to be present in poultry waste. The finding also revealed that, body weight and body weight gain of ducks fed diets with 15 and 20\% DPW were lower than in other groups. The adverse effect of the high level of DPW may be attributed to $2 / 3$ of the nitrogen in DPW is uric acid which has been shown to be unavailable and possibly toxic to the ducks. The variability in the effect of DPW on growth rate of ducks may be ascribed to the quality of the undegraded protein in the droppings and to the extent to which the diets meets the requirements of the ducks.

The data related to the feed intake were agreed with that found by Momtaz and Abidur (1990) who found that, there was no significant difference in feed intake between duckling groups fed on diets contained $0,5,10$ or $15 \%$ poultry droppings. Moreover, Udedibie and Omekam (2001) found that, feed intake of broilers fed diets contained 0, 5, 10, 15 and $25 \%$ DPW were significantly $(\mathrm{P}<0.05)$ decreased only at the level of $25 \%$. At the same time, the finding results disagreed with that reported by Ali et al. (1995) who recorded that inclusion of poultry manure in the broiler diet up to $20 \%$ might reduced or increased the feed intake. The increase in feed intake in our results with higher levels of DPW in the diet may be attributed to the higher crude fibre content of DPW.

The inclusion of dried poultry waste at the levels of $0,5,10,15$ and $20 \%$ to the diets of growing ducks did not significantly $(\mathrm{P}>0.05)$ influence the feed conversion ratio at any growth phase. A result which was in line with earlier findings of Momtaz and Abidur (1990) who reported that, there were no significant differences in feed conversion 
between duckling groups fed on diets contained $0,5,10$ or $15 \%$ poultry droppings. There were no significant differences in FCR among diets containing DPW at the level of 5-30\% (Biely and Stapleton, 1976 and Gahain et al., 1993). On the contrary, the present results disagreed with that reported by pervious studies (Adeyemo and Oyejola, 2004) who concluded that, FCR was significantly decreased by the adding of DPW to the broiler diets. The slight decrease in FCR in our results may indicate that, DPW was lower in energy than we had estimated in formulating rations.

There were no significant difference in protein efficiency ratio and caloric efficiency ratio between the control and tested groups throughout the experimental period. The value of PER and CER were decreased by increasing the level of dried poultry waste in the diets. Birds fed diet with 20\% DPW recorded the lowest one. These results were agreed with that found by Saikia et al. (1988) who found that, PER was decreased with increasing the levels of DPW in the diets of broiler chickens. On the contrary, Ali et al. (1995) reported that, the PER increased with increasing the level of DPW. Regarding mortality rate, ducks fed diet with 0,5 and $10 \%$ dried poultry waste had no mortalities during the experiment while, feeding diets with 15 and 20\% DPW were accompanied by 8.33 and $25.0 \%$ mortalities, respectively. These data agreed with that found by Mosaad et al. (2005) who reported that broiler chicken fed $15 \%$ dried poultry waste having a mortality rate of $25 \%$. On the contrary, the results disagreed with that reported by Biely and Stapleton (1976) and Elizabeth et al. (1978) who found that, mortality rate was negligible when broiler chicks were fed on diets with $0,5,10$, 15 and $20 \%$ dried poultry waste.

\section{Blood parameters}

The results in table 4 illustrated that, there were no significant differences in the blood parameters between groups fed different levels of dried poultry waste. These results were agreed with that reported by El-Kerdawy et al. (1993) and Abdel-Azeem et al. (2007) who found that, total protein and its fractions and urea did not differ significantly when dried layer manure was added up to $30 \%$ in rabbit diets. Panda et al. (2007) reported that, sun dried caged layer manure up to $10 \%$ in the diet of broiler chickens did not influence serum concentration of albumin and globulin. However, the concentration of serum protein decreased and that of uric acid increased by incorporation of sun dried caged layer manure at $7.5 \%$ in the diet. Abdel-Azeem et al. (2007) found that, rabbits fed diets with $15 \%$ dried broiler manure gave the highest 
significant $(\mathrm{P}<0.05)$ value for plasma proteins, while the lowest value was recorded with rabbit received the control diets. In addition, there were no significant effect $(\mathrm{P}>0.05)$ in values of albumin, globulin, $\mathrm{A} / \mathrm{G}$ ratio and urea between the rabbits given different dietary levels of two manures (dried broiler manure and dried layer manure ) when compared with those fed control diet.

\section{Carcass trait parameters}

The data in table 5 revealed that, the dressing $\%$ and relative percentage of internal organs of ducks fed on DPW was strikingly similar to that of the control diet. The diets were isocaloric which did not led to significant differences in dressing. These results are in agreement with those obtained by Adeyemo \& Oyejola (2004) and Mosaad et al. (2005) and Abdel-Azeem et al. (2007) who showed that, dietary DPM did not affect neither dressing percentage nor percentage of internal organs in broilers and growing rabbits. El-Deek et al. (1995) found that, there were no significant differences among groups of muscovy duckling fed on $10 \%$ sun dried layer manure in the dressing percentage and weights of the internal organs.

\section{Economical evaluation}

Data in table 6 showed that, the price $/ \mathrm{kg}$ feed was decreased with increasing the level of dried poultry waste. It was observed that, duck groups fed diets containing DPW at levels 5, 10 and 15\% had higher economic feed efficiency (EFE) when compared to those received the control diet. However, ducks fed diet with $20 \%$ DPW had lower economic feed efficiency. The results are in agreement with that reported by Momtaz and Abidur (1990) who found that, feeding of ducks on diets containing $15 \%$ poultry droppings was economic and had no side effect. It could be concluded that, addition of dried poultry waste to the duck diets up to $10 \%$ leads to decrease in the cost of the ration without any adverse effect on the duck performance.

\section{REFERENCES}

Abdel-Azeem, F.; El-Bordeny, N.E. and Khorshed M.M. (2007): Efficacy of biogen in improving the utilization of dried poultry manure in rabbit diets. Egypt. J. of Rabbit Science, 17 (1): 119-138.

Adeyemo, A.I. and Oyejola, O. (2004): Performance of Guinea fowl Numida Meleagris fed varying levels of poultry droppings. International J. of Poultry Science, 3 (5): 357-360. 
Ali, Y.; Saikia, A.; Baruah, K.K. and Saikia, B.N. (1995): Evaluation of dehydrated poultry manure as feed ingredients for broilers. J. of the Assam Veterinary Council, 5: 25-27.

A.O.A.C. (1990): Official Methods of Analysis. Association of Official Analytical Chemists, $15^{\text {th }}$ Edition, Washington, D.C. USA.

Arndt, D.L.; Day, D.L. and Hotfield, E.E. (1979): Processing and handling of animal excreta for refeeding. Journal of Animal Science, 48 (1): 157-161.

Attia, F.M.; AL-Sobayel, A.A.; Bayoumi, M.S. and Haroun, I.Y. (1993): Body composition of two commercial strains subjected to early feed restriction or feeding with dried chick excreta. Anim. Sci and Tech. 44 (1-2): 85-91.

Biely, J. and Stapleton (1976): Recycled dried poultry manure in chick starter diets. Br. Poult. Sci.; 17: 5.

Carpenter, K.J. and Clegg, K.M. (1956): The metabolizable energy of poultry feedingstuffs in relation to their chemical composition. J. Sci. Food Agri., 7: 45-51.

Christopher, D.; Pierre, C. and Claude, C. (1997): The impact of livestock and fisheries on food availability and demand in 2020. American J. of Agriculture Economics, 79 (5): 1471-1475.

El-Boushy, A.R. and Vink, F.W.A (1977): The value of dried poultry waste as a feedstuff in broiler diets. Feedstuffs, 49 (51): 24-26.

El-Boushy, A.R.Y. and Van Der Poel, A.F.B. (2000): Hand book of poultry feed from waste: Processing and Use, $2^{\text {nd }}$ edition, Kluwer Academic Publishers, Dordrecht.

El-Deek, A.A.; Attia, Y.A.; El-Samra, A.E.; Marfat Saleh, E. and Aser, M.A. (1995): Influence of feeding layer manure and rumen content on growing duckling performance. Egypt. Poult. Sci., 15: 169-203.

Elizabeth, V.K.; Venugopalan, C.K. and Unni, A.K.K. (1978): Utilisation of dried poultry manure in broiler rations. Kerala Journal of Veterinary Science, 9 (2): 235-240.

El-Kerdawy, D.M.A.; Ahmed, S.S. and Ibrahim, H. (1993): Effect of feeding layers manure on growth, slaughter traits, physiological aspects and nutrients digestibility in meat rabbits. Egyptian Journal Rabbit Science, 3 (1): 55-71.

Fontenot, J.P. And Webb, K.E. (1975): Health aspects of recycling animal wastes by feeding. J. Anim. Sci., 40: 1267. 
Gahain, A.K.; Siakia, A.; Konwar, B.K. and Ahmed, H.F. (1993): Utilisation of sun-dried poultry litter waste in broiler ration. Poultry Adviser, 26 (6): 39-43.

Hady, Maha, M. (1989): Influence of feeding diets containing dried poultry manure on broiler performance. Zagazig. Vet. J. $(7,4)$ : 116-125.

Henuk, Y.L. and Dingle, J.G. (2002): Poultry wastes: Current problems and solution. In: Global perspective in livestock waste managements: Proceeding of the $4^{\text {th }}$ International Livestock Waste Management Symposium and Technology Expo, Penang, Malaysia, 19-23 May 2002, pp. 101-111.

Janssen, W.M.M.A. (1989): European Table of Energy Values for Poultry Feedstuffs. 3 rd ed. Beekbergen, Netherlands. Spelderholt Center for Poultry Research and Information Services.

Kaplan, L.A. and Pesce, A.J. (1996): "Clinical Chemistry", Mosby Ed.

Marshall, W.J. (1989): Illustrated Textbook of Clinical Chemistry, $3^{\text {rd }}$ ed. London, Gower Medical Publishing, 207-218.

Momtaz, M. and Abidur, R. (1990): Effect of partial replacement of calorie and protein in the rations of ducklings with poultry droppings. Bangladesh Journal of Animal Science, 19 (1\&2): 45-52.

Mosaad, G.M.; Abdel-Raheem, H.A. and Sayed, A.N. (2005): Dried poultry droppings as a non conventional feed ingredient in broiler diets. Assuit Vet. Med. J., 51(106): 67-83.

Nambi, J.; Mbugua, P.N. and Mitaru, B.N. (1992): The nutritive evaluation of dried poultry excreta as a feed ingredient for broiler chickens. Animal Feed Sci. and Technology, 37 (1-22): 99-109.

N.R.C. (1994): Nutrient requirements of poultry. $9^{\text {th }}$ ed National Academy press, Washington, D.C., USA.

Olorede, B.R.; Ajagbonna, O.P. and Babatunde, G.M. (1995): Comparison of air-dried and oven-dried poultry droppings in broiler rations. Effect of performance, organ weights and hematological parameters. International Journal of Animal Science, 10: 289-293.

Onimisi, P.A. (2005): Evaluation of ginger waste meal as energy source in the diets of broiler chicken. M. Sci. Thesis submitted to the Department of Animal Science, Ahmadu Bello University, Zaria, Nigeria. 
Panda, A.K.; Rao, S.V.R. and Raju, M.V.L.N. (2007): Dietary incorporation of sun dried cage layer manure on performance of broiler chickens $\$$. Indian Journal of Animal Science, 77(12): 1326-1329.

Patton, C.J. and Crouch, S.R. (1977): Anal. Chem., 49: 464-469.

Saikia, B.N.; Saikia, A.; Baruah, K.K.; Das, P.C. and Saikia, G.K. (1988): Dried poultry manure and dried cow dung manure in combination as feed substitutes in broiler rations. Poultry Adviser, 21 (5): 21-25.

Smith, L.W. (1981): Research needs on the utilization aspects of the feeding of animal waste. Journal of Animal Science, 52: 902-905.

SPSS 11 (2001): Statistical Software Package Program Social Science. Spss. Inc. USAS

Udedibie, A.B.I. and Omekam, V.N. (2001): Nutritional and health implications of dietary inclusion of dried poultry waste (DPW) for broilers. Agro-Science - Journal of Tropical Agriculture, Food, Environment and Extension, 2 (1): 24-29.

Vander Zijipp, A.J. (1997): Animal Food Production. The perspective of human consumption, production, trade and disease control. Livestock Production Science. 58: 199-206.

Young, D.S. (2001): Effects of disease on Clinical Lab. Tests. $4^{\text {th }}$ ed. AACC. 